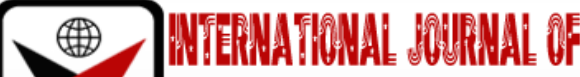 \\ ZmRक
}

ISSN 2278 - 0211 (Online)

\section{The Southern African Development Cooperation (SADC): Its Relevance in the African Continent}

\begin{tabular}{c}
\hline Dr. Idorenyin Eyo \\
Lecturer, Department of Law, University of Uyo, Nigeria \\
Akebong Essien \\
Doctoral Candidate, Department of Law, University of Uyo, Nigeria
\end{tabular}

\begin{abstract}
:
Regional integration is practiced all over the world. Africa is no exception. Different regional organizations exist in Africa, amongst which is the Southern African Development Community (SADC). The SADC is made up of countries mainly in the Southern part of Africa. It promotes healthy collaborations, economic integration and technical cooperation amongst its members. This paper analyses the objectives, organs, achievements and failures of the SADC. It is pertinent to state that the relevance of the SADC in the African continent cannot be overemphasized. There is however the need for stronger ties between its members. There is also the need for the strengthening of SADC's organs. in order for it to have greater impact, both within and outside Africa.
\end{abstract}

Keywords: Southern Africa, regional, integration

\section{Introduction}

Regional integration is very popular all over the world today especially after the cold world. While new ones are being established, old ones are revived. This is not an exception for us in Africa as the promotion of regional integration remains an important economic and political goal. It has a fairly long history in virtually all parts of Sub-Saharan Africa. A number of leaders called for the integration of Africa already soon after independence, but it was only in the 1970s and 1980s that concrete steps were taken to re-launch or establish economic integration institutions in all subregions. ${ }^{1}$ Regional integration is driven by considerable potential for a more robust and equitable economic growth as well as the need to create and promote equal competitive opportunities for member states. It is viewed as the key to boosting productivity and achieving lasting improvements in living standards. ${ }^{2}$ Generally, regional integration increases competition in the local market, which in turn increases productive efficiency and price convergence across countries and regions. Regional integration also promotes the transmission of technological innovation and enables countries to compete with more advanced economies on the international market. In addition, it creates incentives for governments to adopt less distortionary domestic policies and more disciplined macroeconomic management. Moreover, it can help regions to achieve economies of scale and build their supply capacity and competitiveness. ${ }^{3}$

It is important to mention from the outset that cooperation between countries can occur on three levels, namely: coordination which involves the voluntary alignment of national policies and investments in certain sectors of the economy. Secondly is harmonization, usually involves adoption of common legislation. Although all legislations are still national and all policies and instruments are nationally controlled and implemented, they might be regionally agreed. Thirdly, Integration, here some of the traditional decision-making powers of nation states have been handed over to the regional level and regional rules and decisions supersede national legislation. Whichever level of cooperation that exists within the region, it is driven by three main factors, namely: political, economic or military factors. Africa's record of regional integration started since African countries started achieving independence in the beginning of the 1960s. Most of them have concentrated on economic integration but regrettably, none has been able to achieve the goal of producing genuine regional economic integration. ${ }^{4}$

Southern African Development Community (SADC) is a regional governmental organization that promotes collaboration, economic integration and technical cooperation throughout Southern Africa. In 1980, nine Southern African states - Angola, Botswana, Malawi, Mozambique, Lesotho, Swaziland, Tanzania, Zambia and Zimbabwe - established the Southern African Development Co-operation Conference (SADCC). The main objective of SADCC was not only to reduce its

1L K Niekerk 'Regional Integration: Concepts, Advantages, Disadvantages and Lesson of Experience' Available at www.siteresources.worldbank.org accessed 17 August 18, 2019

2 S Kayizzi-Mugerwa, J. C. Anyanwu and P Conceicao, 'Regional Integration in Africa: An Introduction' (2014) African Development Review, 26(1) Pp. 1-6 3 ibid at 2

${ }^{4}$ H Heinonen 'Regional Integration and the State: The Changing Nature of Sovereignty in Southern Africa and Europe' A Doctorate Dissertation Submitted to Institute of Development Studies (IDS) University of Helsinki 2006 
members' economic dependence on the Republic of South Africa that gained dominance over the region but to start a process of regional political and economic integration between the so-called frontline states. ${ }^{5}$ The main objective of this organization was to reduce its members' economic dependence on the Republic of South Africa but also to start the process of regional political and economic integration between the 'front-line states.' The end of the apartheid regime in South Africa (in the beginning of the 1990s) changed the regional context where SADCC operated and in 1992, the organization transformed into a Southern African Development Community (SADC).

\section{Conceptual Framework/Definition}

\subsection{Southern African}

According to Hannu Heinonen, ${ }^{6}$ the first task a researcher has in discussing the concept of the SADC is to define and understand the term 'Southern Africa' as used in that context. To him, that is a difficult task, as the SADC leaves plenty room for interpretation in respect of prospective membership. ${ }^{7}$ Article 8 of the SADC Treaty states that: 'any state not listed in the preamble to the Treaty may become a member of the SADC upon being admitted by the existing members and acceding to this Treaty.' The Council of Ministers has also accepted a more detailed list of criteria for new members, to wit: Applicants should fulfill the following criteria8:

- Geographical proximity to the SADC region;

- Commonality of political, economic, social, cultural systems with the systems of the SADC region;

- Feasibility of cost-effective and efficient co-ordination of economic, social and cultural activities under the SADC framework of co-ordination;

- Absence of a record of engagement in subversive and destabilization activities and territorial ambitions against any SADC or any of its member states;

- Must be democracy, observing the principles of human rights and the rule of law;

- Must share SADC's ideals and aspirations.

During the 1990s, SADC accepted five new members to its organization. Two of these, the Republic of South Africa and Namibia, belong obviously to the region while Mauritius, Madagascar, the Seychelles and the Democratic Republic of Congo (DRC) naturally belong to the eastern coast of Africa. By doing this, SADC has enlarged beyond its natural area and at the moment, the organization has members that are geographically far away from the region or could also belong to some other region. ${ }^{9}$

\subsection{Integration}

Ernest Haas defined integration as follows:

The process whereby political actors in several distinct national settings are persuaded to shift their loyalties, expectations and political activities toward a new centre, whose institutions possess or demand jurisdiction over pre-existing national states. The end result of a process of political integration is a new political community, superimposed over the pre-existing ones. ${ }^{10}$

Integration thus seems to be a process in which states engage themselves in cooperation with other states, which will bring them all the time closer together. Or as the founders of the European Economic Community (EEC) elegantly formulated in the Treaty of Rome, 'to lay the foundations of an ever-closer union among the people of Europe'11

\section{Historical Evolution of SADC}

The idea of 'Southern Africa' as a coherent region is a relatively recent one. It is argued by Immanuel Wallerstein and Sergio Vieira, ${ }^{12}$ as a construct of the $20^{\text {th }}$ century, with a pre-history that can be traced back at most to the 1870 s. For them, the starting point has to do with global force, notably the decline of the British Empire, as well as global economic stagnation, which led to the notorious 'scramble for Africa' by various European powers. In the context, two factors played prominent role in shaping Southern Africa's future. The first is its extraordinary mineral wealth, and the second, its relatively large and permanent settler populations. A struggle ensued for political control of the region. African kingdoms were defeated in battles, and forced to sign disadvantageous treaties. They were partially or totally dispossessed of their land, which was included in new political units established by colonial authorities. At the turn of the $19^{\text {th }}$ century, Britain also declared war against the Boer Republics in the South African interior and defeated them as well. By 1910, the current

\footnotetext{
5 ibid

${ }^{6}$ ibid at 143

7 ibid

${ }^{8}$ In the Dar es Salaam Submit in Tanzania, 2003, SADC adopted new criteria for the admission of new members. However, it did not change the original criteria but only streamlined the admission procedures. According to the current system, the secretariat will assess the country applying for membership on the basis of the criteria and make appropriate recommendations to the Council which will in turn make recommendation to the summit. See J Sidaway and R Gibb, 'SADC, COMESA, SACU: Contradictory Formats for Regional 'Integration' in Southern Africa? In: Simon (ed) South Africa in Southern Africa: Reconfiguring the Region (James Curry, Oxford, 1998) 164 - 184 at 170

${ }^{9} \mathrm{H}$ Heinonen (n4) at 144

${ }^{10}$ E B Haas, 'The Legacy of Neo-functionalism' Journal of European Public Policy (1968) 12(2) at 16. See also, P C Schmitter, 'The Disparity of European Integration: Revisiting Neofunctionalism in Honour of Ernest Haas' Journal of European Public Policy (2005) 12 (2)

11 See the Preamble establishing the EEC

12 I Wallerstein and S Vieira, 'Historical Development of the Region in the Context of the Evolving World-System' In: S Vieira, W Martin and I Wallerstein (eds), How Fast the Wind? Southern Africa, 1975-2000 (Trenton: Africa World Press, 1992)
} 
political boundaries in the region were largely in place. This was followed by the creation and consolidation of the political and material infrastructure needed to govern the region and build and manage western-style economics, largely based on exporting primary products such as diamonds, gold and coal. In 1948, however, the Anglo-Boer political compromise of 1910 was undone by the ascent to power of the Afrikaner-led National party, which introduced the notorious policy of formal racial separation, or apartheid. This led to the creation of an elaborate system of oppression and marginalization and generated a large pool of cheap African labour (drawn from the entire sub-region) that was vital for the establishment of the country's industrial base. ${ }^{13}$

The Nationalists sought to project South Africa as a country with its own hinterland, the neighbouring states of States of Southern Africa. However, other countries in the region strongly resisted its attempts at regional dominance (conceptualized by the ruling National Party as a 'constellation of Southern African states'). This ran headlong into the dramatic decolonization dynamic that swept large parts of Africa from 1954 onwards. In the early 1970s, Angola, Mozambique, Namibia and Zimbabwe were fighting wars of liberation. In 1970, the Portuguese government was overthrown by its military, which led to the independence of its colonies, including Mozambique and Angola, a year later. Far from bring stability; the new political order introduced new uncertainty. Civil war in Angola brought external factors including Cuba, the Soviet Union and South Africa into the fray. Countries in the region felt the impact of these conflicts as well as the apartheid state's interventionist and violent policies and created the Front-Line States (FLS) alliance in response. ${ }^{14}$

From the foregoing, it could be summed up that the origin of the integration process of the SADC lies in the ideological war that backed the political liberation movements of the 1960 and 1970s - from both colonialism and whiteminority governments - that swept through Southern Africa. During this period, the leaders of Angola, Botswana, Mozambique, Tanzania and Zambia formed a loose political coalition known as 'the Frontline states', where members agreed to coordinate their political, diplomatic and military resources in order to help further decolonization and effectively combat the destabilizing and expansionist agendas of the oppressive, retrograde and racially discriminatory regimes in South Africa and the former Rhodesia (now Zimbabwe). This coalition resulted in the Lusaka Summit held in April 1980 that gave birth to SADCC.15 The primary objectives of the SADCC were to coordinate the economic and diplomatic resources of its members so as to reduce members' dependence, particularly but not only on apartheid South Africa, create links and strengthen relationships between members to contribute to equitable regional economic integration, promote the implementation of policies that would have an interstate and regional impact and attain and secure international support for the SADCC's quest for economic liberation and self-reliance in the region. ${ }^{16}$

The SADCC operated within a decentralized framework with each member state assuming complete responsibility for the coordination, administration and project implementation of one or more of the 21 different sectors - for example, Swaziland had responsibility for the human resource development sector whilst Zambia handled employment as well as labour and mining. ${ }^{17}$ It was felt that this decentralized division of labour would give each member an equal standing in the SADCC hierarchy, not to mention preventing the need for a large and expansive bureaucracy that would have followed from any centralized governing institution. However, as member states were legally responsible for their projects, the SADCC did not itself have any legal status. ${ }^{18}$ In 1989 , leaders of the SADCC met in Harare, Zimbabwe and decided that SADCC should be formalized and ratified with 'an agreement', Charter or Treaty. On 17th August 1992, at a summit held in Windhoek, Namibia, the Heads of State and government of SADCC member states as well as Namibia - which had gained independence from apartheid South Africa's mandate two years earlier - signed the SADC Treaty and Declaration; establishing the formation of the South Africa Development Community (SADC). The creation of the SADC was largely motivated by two primary geopolitical factors. On the one hand, it had become increasingly apparent by the end of the 1980's that the apartheid government in South Africa was losing its hegemonic grip on the country. Namibia achieving independence from three quarters of century of South African rule and the swearing in of Sam Nujoma as the first democratically elected president of Namibia on 21st March 1990 - a ceremony attended by Nelson Mandela, a month after being released from his 27-year imprisonment. On the other hand, the fall of the Berlin Wall on 9th November 1989 and the end of the Cold War marked the beginning of an international trend toward neo-liberalism. This brought with it the subsequent challenges of globalization, privatization and competitive regional markets and leaders realised that they had to respond in kind. The establishment of a legally binding regional politico-economic bloc would not only enable members to more effectively encourage and support each other in reforming their economies, liberalizing trade, fostering private sector growth and attracting foreign investment but also allow the region to compete globally as an economy of scale.

The SADC therefore differed significantly from its predecessor. ${ }^{19}$ Whereas, the SADCC was an informal association of neighbouring states whose shared aim was largely the coordination of national affairs in a regional context for mutual benefit, the SADC represented a largely established inter- state organization that pursued a comprehensive regional integration agenda to foster-economic growth, respond to the many challenges of neoliberalism and compete internationally as a global player.

${ }^{13}$ A van Nieuwkerk, Towards Peace and Security in Southern Africa: A Critical Analysis of the Revised Strategic Indicative Plan for the Organ on Politics, Defence and Security Co-operation of the Southern African Development Community' (Maputo-Mozambique, Friedrich Ebert Stiftung Publishers, 2012) at 8 14ibid

${ }^{15}$ A Barlow, 'The Southern African Development Community: History to 2001'(2015). Available at https://www.hsf.org.za accessed 18 August 2019.

${ }_{16} \mathrm{Cf}$. the overview and Analysis of the History of SADCC in I Mandaza \& A Tostensen, Southern Africa in Search of a Common Future: From the Conference to the Community, Gaborone: SADC 1994 AND k Lambrechts, 'The SADC's Origins' In: The IGD Guide to the Southern African Development Community (Johannesburg: Institute for Global Dialogue, 2001)

${ }^{17}$ seewww.dfa.gov.za/foreign/multilateral/africa/sadc.htm. Accessed 8 August, 2019

${ }^{18}$ www.jiclt.com/index.php/jiclt/article/view/74/73 Accessed 8 August, 2019

${ }^{19}$ According to Article 3 (1) of the Amended Treaty SADC, 'SADC shall be an international organization and shall have legal pers onality ... 
Following the fall of Apartheid, South Africa was admitted to the SADC in 1994, Mauritius joined a year later in 1995, Seychelles ${ }^{20}$ and Democratic Republic of Congo in 1998 and Madagascar in 2005.SADC ${ }^{21}$ leaders had recognized that the decentralized cooperation framework inherited from SADCC could not effectively support the ambitious integration agenda of the SADC and in fact arguably worked against it. Lacking a centralized structure monitored by a rules-based mechanism within which policy directors were compiled to operate, SADC objectives too often and too easily played second fiddle to national interests. As one commentator remarked, ${ }^{22}$ 'the policy organs, in form of the summit and Council, assumed a role of both a player and referee in the integration game. Centralization was seen as necessary to ensuring that regional objectives were adhered to. ${ }^{23}$ Also of significance was the approval of the following two strategic plans: The Regional Indicative Strategic Development Plan (RISDP) and the Strategic Indicative Plan for the Organ (SIPO). ${ }^{24}$ The purpose of the RISDP is to deepen regional integration. It is the framework in which the SADC pursues its socio-economic objectives. It highlights poverty eradication, gender equality and the fight against the HIV/AIDS as among the most important policies under the SADC's remit.

The purpose of the SIPO is to be an 'enabling instrument' used to contribute towards the creation and maintenance of peace and security in the region in order for the SADC to effectively meet its socio-economic objectives. ${ }^{25}$ The SIPO provides the implementation framework in which the SADC's defence and security body - the organ on politics, defence and security co-operation - operates. It complements the security role played by the African Union and emphasizes the areas of the Standby Force, the safe-guarding of democracy, human rights and the fight against corruption as of particular importance. The 2004 foreword to the SIPO document notes:

The SIPO is not an end in itself ... it is an enabling instrument for the implementation of the SADC developmental agenda embodied in the Regional Indicative Strategic Development Plan (RISDP). The core objective of the SIPO, therefore, is to create a peaceful and stable political and security environment through which the region will endeavour to realize its socio- economic objectives. ${ }^{26}$

\section{Membership and Allied Matters}

The SADC is established for an unlimited period of time, but the SADC Treaty includes articles which clearly stipulate rules about withdrawal from membership and dissolution of the whole organization. The EU Treaty did not originally mention a possibility to withdraw from membership, which reflected the idea that joining the organization is a permanent act. With the new constitution, the situation has changed and the new constitution also includes about voluntary withdrawal for members. According to Article 34 of the SADC Treaty, any member of the SADC can also withdraw from membership in the organization after a period of notice which is one year. The Summit can also decide with a three-quarters majority to dissolve the SADC. Therefore, it can be concluded that when signing the Treaty, member states are obviously committed to the objectives of the organization and to the process of regional integration but at the same time they hold the right to withdraw from the process at any point if they so choose. It could be argued that such article in the SADC may reduce the credibility of the commitments of member states in the process. ${ }^{27}$

\section{SADC's Organizational Structure and Decision-Making Procedure}

The SADC organizational structure comprises of: The Summit of Heads of States or Governments, the Summit Organ on Politics, Defence and Security, ${ }^{28}$ Council of Ministers, Sectoral and Cluster Ministerial Committees, Standing Committee of Senior Officials, the Secretariat, National Committees, Parliamentary Forum and Tribunal ${ }^{29}$. The Summit of Heads of State or Government, according to the Treaty of the SADC, is the supreme policy-making institution of the SADC. It is led by a Troika system consisting of the Chairperson, the incoming Chairperson and the outgoing chairperson. It will, according to the new Treaty, meet at least twice a year. ${ }^{30}$ The first meeting will take place in before 31 March each year and is intended to focus primarily on regional economic development matters and the SADC Programme of Action. The

${ }^{20}$ Seychelles withdrew in 2004 as a result of their inability to meet the financial obligations.

21 SADC currently has fifteen membership, namely, Angola, Botswana, Democratic Republic of Congo, Lesotho, Tanzania, Malawi Mauritius, Mozambique,

South Africa, Seychelles, Zambia, Zimbabwe, Swazilannd, Namibia,

${ }^{22} \mathrm{H}$ Heinonen (n4)

${ }^{23}$ ibid

24 In January 2002, the SADC Summit mandated the OPDSC to prepare a Strategic Indicative Plan for the Organ (SIPO) which would provide guidelines for implementing the Protocol on politics, Defence and Security Co-operation over the next five years.

2525 SIPO was designed to achieve three objectives: first, to provide guidelines for action (strategies and activities); shape the institutional framework for the day-to-day activities of the organ (including the operationalization of the protocol and the Mutual Defence Pact); and align SADC's peace and security agenda with that of the AU (particularly the AFS and aspects of good governance). See A van Nieuwkerk (n13)

${ }^{26}$ A van Nieuwkerk, Southern African Security Governance: A Cautionary Tale In: G Cawthra (ed), African Security Governance: Emerging Issues

(Johannesburg: Wits University Press, 2009) at 108

${ }^{27} \mathrm{H}$ Heinonen (n4)

${ }^{28}$ In 1996, SADC decided to create this organ. It never became operational as a variety of problems erupted starting from chairing of the organ, the permanency of that position and its status. See A van Nieuwkerk, 'Regionalism into Globalism? SADC and Ecowas Compared' Africa Security Review, (2001) 10 (2), 7-18

${ }^{29}$ Article 14 of the Tribunal Protocol provides for the jurisdiction of the Tribunal which covers, for example, the interpretation and application of the Treaty as well as the Protocols. It also has jurisdiction over disputes between natural or legal persons and states, which could be seen as a sign of the direct effect of the SADC legal order. Article 16 of the same Protocol denotes that the Tribunal has a right to give preliminary rulings in cases referred to it by national court and according to the Protocol, the Tribunal shall only apply 'the Treaty, this Protocol and other Protocols that form part of the Treaty, all subsidiary instruments adopted by the Summit, by the Council or by any other institution or organ of the Community pursuant to the Treaty or Protocols'. See Article 16 and 21 of the Tribunal Protocol. Article 32 of the Tribunal Protocol raises the question whether the Tribunal can take an influential role in Southern Africa. This question is related to the enforcement of the Tribunal's decisions and sanctions imposed on member states. The enforcement of the Tribunal decision is handed over to national level and national institutions.

${ }^{30}$ It consists of the Heads of State or Government of all member states, meeting at least once a year. 
second will take place in August/ September and is dedicated to political matters. Decision will be taken by consensus and will be binding. ${ }^{31}$ The Summit is responsible for the overall policy direction and control of the organization and its various functions, which includes, for example, reviewing the Regional Indicative Strategic Development Plan (RISDP) (that is, the SADC's main socio-economic development plan). ${ }^{32}$ The summit uses the consensus rule for taking decisions. Each country has one vote which means that the members have equal power in the decision-making process. Thus, in principle, each state has the right to veto any decision, ${ }^{33}$ giving individual members supreme power over all decision-making. The sovereign equality principle is highly entrenched in SADC's political culture. However, there are some exceptions to the consensus rule. For example, when amending the SADC Treaty, weighted voting is practiced. Three quarters of all members have to approve the amendment. Also, decisions regarding admittance of new members are based on unanimity.

The SADC Council of Ministers ensures policies are implemented properly; the Standing Committee of Senior Officials serves as technical advisory committee to council. The Sectoral and Cluster Ministerial Committees is made up of Ministers from each member state serve on committees with oversight function on the core areas of integration and control implementation of RISDP in areas of competence such as trade, industry, finance and investment, infrastructure and services, food, agriculture, natural resources and environment, social, human development and social programmes (such as HIV/AIDS, education, employment and gender), legal affairs and judicial matters, politics, defence and security. ${ }^{34}$ The Secretariat is the principal executive institution responsible for planning, coordination and management of all SADC programs. It comprises of the Executive Secretary, ${ }^{35}$ Deputy Executive Secretary (Regional Integration) ${ }^{36}$ and Deputy Executive Secretary (Finance and Administration). ${ }^{37}$ The SADC National Committees are key stakeholders from government, private sector and civil society in each member state. They make inputs at the national level in the formulation of regional policies and strategies. Coordinates and oversees implementation of programs at national levels and initiates SADC projects and issues paper in preparation of regional strategies. ${ }^{38}$ The SADC Parliamentary Forum is a regional inter-parliamentary body of members of Parliaments of SADC member states which provides a platform to support and improve regional integration through parliamentary involvement, promote best practices in the role of parliaments in the regional integration and cooperation. Finally, the SADC Tribunal is an organ supposed to ensure adherence to proper interpretation of SADC Treaty and subsidiary instruments and adjudicate upon disputes referred to it. However, its operation was suspended in $2010 .^{39}$

The SADC has legislative (that is, decision making) powers. The general rule is that the SADC applies unanimous decision-making. As earlier stated, the Summit is the supreme policy -making institution of the SADC. The Summit works on the basis of consensus unless otherwise stated in the Treaty. ${ }^{40}$ The two most important decision-making competencies of the Summit are related to amending the SADC Treaty and approving new Protocols. Interestingly, in the case of amending the Treaty, the Summit uses majority decision-making (three quarters), while in approving protocols the general rule of consensus is followed. The Council of Ministers also makes decisions on a basis of consensus. ${ }^{41}$

The SADC also has executive power. According to the SADC Treaty, the secretariat is the principal executive institution of the SADC. The restructuring of the 1990s gave the Secretariat more power also in the implementation of decisions of the SADC Summit, Organ of Politics, Defence and Security Co-operation and the Council. Part of its executive powers is the enforcement power of the organization to impose sanctions on a member state. ${ }^{42}$ These sanctions can be imposed if a member state fails to, for example, fulfil its obligations assumed under the Treaty or implements policies which undermine the principles and objectives of the SADC. However, according to the Treaty, 'the sanctions shall be determined by the Summit on a case-by-case basis'.43

The SADC also has judicial powers. Its Treaty provides for the establishment of a Supranational Court called the Tribunal. At the moment the Protocol on Tribunal and the Rules of Procedures has been signed. ${ }^{44}$

\footnotetext{
31J Isaksen and E N Tjonneland, 'Assessing the Restructuring of SADC - Positions, Policies and Progress' A Report Commissioned by the Norwegian Agency for Development Co-operation (NORAD) December 2001

${ }^{32}$ www.internationaldemocracywatch.org accessed 19 August, 2019. RISDP is the blueprint of SADC's regional integration plans and a comprehensive development and implementation framework guiding the Regional integration agenda of the Southern African Development Community (SADC), covering a period of fifteen years (2015-2020). It is designed to provide clear strategic direction with respect to SADC programmes, projects and activities in line with the SADC common agenda and strategic priorities, as enshrined in the SADC Treaty of 1992 . The ultimate objective of this plan is: to deepen integration in the region with a view to accelerate poverty eradication and the attainment of other economic and non-economic development goals. The core of SIPO, which is linked with RISDP, is to create a peaceful and stable political and secure environment through which the region will realize its objectives of socio-economic development, poverty eradication and regional integration.

${ }^{33}$ It is obvious that the decision-making system involves a very high degree of protection of member states' national interests. Decisions cannot be made without the consent of all member states' national interests. Decisions cannot be made without the consent of all members, which guarantees that any member can de facto veto all decisions that would violate their national interests. Furthermore, in the case of Protocols, me mber states can also attempt to hinder their ratification by delaying their national ratification processes. SeeHeinonen (n4)

${ }^{34}$ Strengthening the Institutional Capacity of the Southern African Development Community (SADC). A Publication of the NEPAD pla nning and coordinating Agency Midrand, South Africa, 2015 available at www.nepad.org or www.africa-platform.org accessed 19 August 2019.

35 In charge of organs of politics, defence and security, internal audit, public relations, gender and macro-economic surveillance

${ }^{36}$ In charge of Trade, industry, finance, investment, infrastructure and services, land, agriculture, natural resources, social, human development and special programmes, policy planning and resource mobilization.

${ }^{37}$ Oversees budget and finance, human resources \& Administration, conference services, procurement, legal affairs, information and communication technology

${ }^{38}$ www.nepad.org accessed 19 August 2019.

${ }^{39}$ Seehttp://www.sadc.int/sadc-secretariat/directorates/ accessed 19 August 2019

${ }^{40}$ Article 10(9) SADC Amended Treaty

${ }^{41}$ Article 11(6) SADC Amended Treaty

42 Article 33

${ }^{43}$ Article 33(2)

44 The powers and jurisdiction have already been discussed in footnote 21 above
} 


\section{Achievements}

While it can be acknowledged that the SADC has, since its inception in 1992, achieved numerous positive developments, the achievements and benefits have been outweighed by the challenges bedeviling the regional bloc. First, the SADC has been able to demonstrate that regional integration and co-operation are possible and desirable. ${ }^{45}$ Secondly, the SADC has been able to inculcate a sense of regional belonging as well as a tradition of consultation among the peoples and governments of Southern Africa. ${ }^{46}$ This has resulted in building of trust and confidence by sharing and exchanging information, particularly co-operation in various defence areas, such as information exchange, visits to and the sharing of training institutions and joint exercises. ${ }^{47}$ According to A van Nieuwkerk, ${ }^{48}$ the achievements of SADC in area of security includes: the introduction of the SADC Mutual Defence Pact which is viewed as a regional commitment in respect of selfdefence and the preservation of peace and security; the launch and operationalization of the SADC Standby Force (SSF) which is seen as a commitment to a collective approach to defence and security affairs; the integration of the Southern African Regional Police Chiefs Co-operation Organization (SARPCCO) into the inter-state Defence and Security Committee (ISDSC), aimed at improving co-operation in respect of policing in the region; and Establishment of a Regional Early Warning Centre (REWC) tasked with helping to anticipate, prevent and manage conflicts. ${ }^{49}$

The regional grouping has also been able to put in place a regional programme of action, namely, the SADC Programme of Action, which encourages cooperation in various economic sectors. ${ }^{50}$ Under the auspices of the SADC a number of infrastructural projects have been undertaken to rehabilitate roads, rail and harbours as a way of improving communication, transportation and carriageways across the region. These achievements, though much still has been achieved, have at least provided a foundation on which the SADC region can make progress towards its regional integration endeavours. On the other hand, progress on issues relating to political governance and the observation of elections via the establishment of the SADC Electoral Advisory Council (SEAC) and a mediation Unit. ${ }^{51}$

Thirdly, the SADC programmes and policies have help in trade liberalization ${ }^{52}$ in the Southern African region. The SADC schedule of implementation of tariff reduction is as follows: an FTA in 2008, in principle, saw up to 85 percent of intra-SADC trade flows duty free, with the remaining 15 percent consisting of sensitive products to be liberalized by 2012 . The rigorous pursuit of bilateral trade arrangements by SADC member states is with a view to promoting enhanced regional trade and promoting further regional integration, thereby promoting economic growth and development within the region. 53

It has also been noted that the SADC has maintained positive growth trends, recording a growth rate of over $4.1 \%$ by 2004.54SADC market has grown exceedingly. The sharp increase attributed to natural growth as well as new member states that have joined over the years, increasing from nine founding nations to the present 14 members. Being aware that regional political stability can divert attention away from economic integration initiatives; hence, the SADC has made considerable strides towards preserving political stability across in the region in order to attract foreign investment. ${ }^{55} \mathrm{On}$ the political front, the region has enjoyed unparalleled peace, political stability and security for the past few years following the signing of the Angolan Peace Accord in April 2002 and the installation in the Democratic Republic of Congo as a transitional government in 2003. The principles and guidelines governing democratic elections have boosted the image of the region as a common investment area and mitigated the risk perception. ${ }^{56}$

\section{The Relevance of SADC in the African Continent}

The role of SADC cannot be underestimated especially in areas such as regional integration, trade and investment, democracy and sustenance of peace and mutual coexistence amongst others. First, to achieve a progressive elimination of obstacles to the free movement of goods, services, capital and labour and of the people generally in the region, regional

\footnotetext{
${ }^{45}$ SADC has endeavoured to create a dynamism which has resulted in a regional identity and a SADC brand name. SADC Handbook: Major Achievements and Challenges (2006) Ch. 1

${ }^{46}$ African Union 'Regional Economic Communities (RECs): Southern African Development Community (SADC): Facts and Figures' (2011). Available at https://www.google.co.zw/?gws_rd=cr\&ei=3Qm3Ur6SG8jAtAbswoAY\#q=Regional+Economic+Communities+(RECs):+Southern +African+

Development+Community+(SADC)\%E2\%80\%9D+Accessed 18 August, 2019

${ }^{47} \mathrm{~A}$ van Nieuwkerk (n13)

48ibid

49 ibidat 10

${ }^{50}$ The organization has managed to formulate a programme of action spanning all the areas of a sectoral and cross-sectoral nature that are critical for the achievement of SADC's objectives, in particular in promoting deeper regional integration, integrati ng SADC into the world economy, promoting balanced and equitable development, eradicating poverty and promoting gender equality. ibid

51 A van Nieuwkerk (n13) at 10

52 Trade liberalization can be explained as the relaxation or elimination of tariffs and removal of duties and / or quotas on exports; alteration in non-tariff barriers such as import quotas and quantitative restrictions, changes in licensing and direct allocation of foreign exchange and in specific regulations for products and removal or relaxation of export subsidies. See H Bienen, The Politics of Trade Liberalization in Africa' Economic Development and Cultural Change, (1990) 38(4), 713-732

53 J Maringwa, 'SADC Regional Integration: What Role has Bilateral Trade Agreements Played in Promoting Intra-Regional Trade? (2009) Trade and Industrial Policy Strategy (TIPS)

54 SADC: Major Achievements and Challenges (2006) at 13.

55 SADC Achievement Handbook, F G Mogae 'SADC Major Achievements and Challenges: 25 Years of Regional Cooperation and Integration' 2005. In order to encourage domestic and international investors in all the areas with development potential, SADC embarked on a programme aimed at inflation targeting, macro-economic stability and the creation of a wider economic space. The region constitutes a small market, smaller than that of Turkey and about one-fifth of the United States market. SADC is focusing on increasing its competitive advantage as a Sub-Saharan Africa destination for investment through deepening cooperation amongst its Member States.

${ }^{56}$ SADC Major Investment Handbook (ibid)
} 
integration becomes important. The SADC Treaty ${ }^{57}$ provides for member states to conclude protocols as may be necessary in each area of co-operation, to achieve the SADC objectives. ${ }^{58}$ Regional integration involves a process of increasing interaction and interdependence in the economic and political arena among a group of countries. Such interactions may be formal (deliberate strategies by political actors in a variety of national settings - formal, state-driven regionalism) or informal (through the market-strategies by private actors). ${ }^{59}$ There is no doubt that SADC has successfully or actively placed this role amongst the member states.

The relevance of trade and tariff liberalization cannot be overemphasized in the growth and development of any regional integration plans. This policy the SADC is pursued as trade and tariff liberalization have been at the heart of the SADC regional economic integration paradigm. The protocol on trade is one of the SADC's earliest legal instruments signed on 24 August 1996 and coming into force on 25 January 2000. The objectives of the Trade Protocol, as amended, are to further liberalize intra-regional trade in goods and services; ensure efficient production within SADC reflecting the current and dynamic comparative advantages of its members; contribute to the improvement of the climate for domestic, crossborder and foreign investment; and enhance the economic development, diversification and industrialization of the region. The Trade Protocol sets the process and modalities for the phased elimination of tariffs and non-tariff barriers within a time frame of eight years from entry into force, that is, by 2008. Tariff phase down schedules were to be completed by 2012. There has been an asymmetric element in tariff phase down time frames depending on the level of development of a member concerned.60

Negotiations on the liberalization of trade in services are also taking place in different forums and at different levels (bilateral, regional and multilateral) using the SADC as a platform. All negotiations are interrelated, since agreement adopted at one level influence developments in others, making the whole negotiating process rather complex. The deeper the level of commitment adopted in the multilateral framework and the wider their scope, the smaller is the space left for preferential liberalization to take place in the framework of bilateral or regional agreements. For instance, in the tourism sector, most of the countries have put not limitations to market access under consumption abroad. ${ }^{61}$ The SADC region has been trading a Preferential Trade Area (PTA) since its inception in 1980. But by January 2008, SADC became a Free Trade Area (FTA). Preferential Trade Agreements (PTAs) as opposed to free trade agreements have greater scope to deal with the whole range of trade obstacles. ${ }^{62}$ Unfortunately,

\section{Failures and Challenges of the SADC63}

Despite the achievements of SADC, it has continued to be bedeviled by various challenges which have impacted negatively on its regional integration efforts as indicated above. Of note has been the domineering position of some member states which have been able to flout regulations and disregard judgments, as in the case of Zimbabwe and the SADC Tribunal judgment. Given Southern African history and developmental profile, securing peace and stability remains a challenge. The Security challenges facing the region are not primarily military but largely political, social and economic. Poverty and underdevelopment are at the heart of the region's human insecurity and given external as well as internal dynamics, insecurity continues to deepen. Essentially, the region faces a dual crisis. It is experiencing a crisis of state building, including the social and psychological dimensions of violence in relation to the perceived security assumed to derive from the state. It is also affected by the global financial and economic crisis: the global political economy tends to reproduce economic insecurity that is prime source of social and political conflict. ${ }^{64}$ It is important to devote a little more space in discussing these challenges.

\subsection{Over Dependence of the Secretariat on Foreign Donors}

The SADC Secretariat in Gaborone lacked the power, authority, capacity and resources required to facilitate regional integration. This is because of its limited capacity to mobilize the region's own resources, including the private sector, for the implementation of the Programme of Action. ${ }^{65}$ The management of complex regional co-operation efforts requires the availability of a pool of political and technical experts. Such expertise is scarce in the region. This is one reason why many sector coordinating units have performed so poorly. The technical capacity in most member countries to

\footnotetext{
57 SADC Treaty was signed on 17 August 1992 and entered into force on 30 September 1993. The Treaty was amended in August 2001. A consolidated text and all its amendments can be accessed at http://www.sadc.int.

58 SADC Treaty (1992) Article 22

${ }^{59} \mathrm{~T}$ Hartzenberg and P Kalenga, 'National Policies and Regional Integration in the South African Development Community' United Nations University World Institute for Development Economics Research, Wider Working Paper 2015/056 (2015)

60 ibid at P. 5

${ }^{61}$ United Nations Conference on Trade and Development titled 'Towards SADC Services Liberalization: Balancing Multiple Imperatives' A Paper Commissioned and Reviewed by UNCTAD - UNCTAD/DITC/TNCD/2008/4 (2010)

620 A Fadeyi, 'Assessing the Impacts of SADC Free Trade Agreements (SADC FTA) on South African Agricultural Trade' A Dissertation Submitted to the Department of Agricultural Economics, Faculty of Natural and Agricultural Sciences, University of the Free State, Bloemfontein, South Africa in Partial fulfillment of the requirements for the degree of M.Sc (Agric.) 2013

${ }^{63}$ See generally SAPES, UNDP \& SADC: SADC Regional Human Development Report 2000: Challenges and Opportunities for Development (Harare: SAPES Books, 2000) and C Clapham et al. (ed.) 'Regional Integration in Southern Africa: Comparative International Perspectives (Johannesburg: South Africa Institute of International Affairs, 2001)

${ }^{64}$ See M Berger and H Weber, 'War, Peace and Progress: Conflict Development, (in)security and Violence in the 21 st Century' Third World Quarterly, 30(1) 2009, Pp 1-16 and A van Nieuwkerk (n13)

65 J Isaksen and E N Tjonneland, 'Assessing the Restructuring of SADC - Positions, Policies and Progress' A Report Commissioned by the Norwagian Agency for Development Co-operation (NORAD) December 2001. See also the Report of the Secretary- General, New York: UN General Assembly July 2001 (A/56/134) and T AEarsda\& J Claussen: Overview of the SADC Program and Donor Cooperation (Oslo: Nordic Consulting Group September 2001) Report Commission by NORAD)
} 
participate and to implement is also very limited. There is no easy solution to this but it underlines the importance of a sharp focus and prioritization of scarce resources. ${ }^{66}$

\subsection{Failure to Reach Agreement}

Failure to reach agreement on the proposed restructuring, in part because of opposition from member countries reluctant to close their coordinating units and increasing the power of the Secretariat. The sector coordinating units in the member states were highly uneven in their ability to pursue and implement policies. SADC's Programme of Action lacks a clear regional focus, it covered too many areas and the majority of projects were mainly national. ${ }^{67}$

\subsection{Growing Political Divisions within the SADC and A Failure to Address Governance, Peace and Security Issues}

The growing dominance of the Republic of South Africa in the SADC creates reluctance in some members of the community to deepen the process of integration which was supposed to be beneficial to all members of the SADC. The fears by some members are that the implementation of economic integration can lead to a situation where most of the benefits of integration concentrate on South Africa and some of the less developed member states can even be worse-off as a result of the integration process. Therefore, the need for the equitable distribution of benefits of economic integration is advocated. 68

\subsection{Different Levels of Economic Development}

The difference in political backgrounds as well as the nature of resources found in different countries has culminated in differences in levels of economic development. It is undisputed that South Africa is the largest economy in the SADC region accounting for over $60 \%$ of all intra-SADC trade and about $70 \%$ of the SADC GDP. ${ }^{69}$ Given these vast economic power asymmetries between South Africa and other members of the SADC, the country cannot be treated as an equal partner. ${ }^{70}$ This has resulted in South Africa being a dominant figure and being able to flout regulations without much protest from other member states. Additionally, South Africa has been able to take its time in negotiating EPAs with the EU, unlike smaller states where South Africa can negotiate on their behalf by virtue of the fact that they are members of the SADC.

In addition, the regional body's major economic challenge has been to create an environment suitable for the attainment of high and sustainable rates of equitable economic growth which, if achieved, would promote economic regional integration. With most SADC member states still experiencing low and decreasing levels of per capita Gross National Product, low growth rates of GDP, relatively high deficient and interest rates, and relatively low savings and investment rates, the economic developments of the region has become increasingly uneven, ${ }^{71}$ a situation which tends to retard economic development as well as regional economic integration.

\subsection{Failure of a Collective Justice System: Case of the SADC Tribunal}

While the idea behind the establishment of the SADC Tribunal (the Tribunal) was a positive development and a big stride towards regional co-operation and integration, disagreements over its composition and functions have tended to present fissures within the regional grouping. The Zimbabwean commercial farmers' case at the SADC Tribunal in Windhoek held high expectations for the SADC Tribunal as a unifying regional institution within the SADC. Given that the Tribunal was a first attempt at seeking to collectively deal with cases of human rights violation at the regional level, and allowing individuals within SADC member states recourse to justice against their respective states, aggrieved individuals held high hopes for putting to an end to the impunity with which the state had trampled on civil liberties. However, the refusal by Zimbabwe to comply with the human rights violations judgment and the subsequent withdrawal of the country from the tribunal presented a test case for SADC regional integration. ${ }^{72}$ The fact that the regional bloc failed to rein in a renegade member state which had blatantly refused to comply with a judgment to compensate the commercial farmers indicates that the SADC cannot enforce some of the provisions of its institutions, in this case the judgment handed down by the SADC Tribunal. Zimbabwe which had been found guilty of the violation of human and property rights by the SADC Tribunal, got away with it and even caused a review of the mandate of the Tribunal. The review culminated in further curtailment of access to justice by SADC citizens by an approach to the Tribunal. The review of the provisions of the Tribunal.

\subsection{Overlapping Membership}

One of the biggest challenges to the creation of a customs union is the overlapping membership of SADC member states in other intergovernmental networks. Namibia and Swaziland for example are both members of the Southern Africa Customs Union (SACU), as well as the Custom Market for Eastern and Southern Africa (COMESA), and both participate in the Regional Integration Facilitation Forum (RIFF). The majority of the states are also COMESA members. A custom union cannot be established as long as countries are members of two or more regional economic communities (RECs) at once.

66 ibid

67J Isaksen and E N Tjonneland (n44)

${ }^{68} \mathrm{H}$ Heinonen (n4)

69 Vickers (2011) at 183

70 ibid

71 SADC: Major achievements and challenges - 25th Anniversary $1980-2005$ (2006) at 74. Available online at

http://www.sadc.int/cms/uploads/SADC\%20Major\%20Achievements\%20Handbook\%20-\%20English\%281\%29.pdf (accessed 17 July 2012).

72 Nathan L. 'Solidarity triumphs over democracy - the dissolution of the SADC Tribunal' United Nations and regional challenges: Development dialogues, papers and comments (December 2011) at 124. 
Furthermore, overlapping membership can be costly, as governments must negotiate in a number of different forums, possibly agreeing to the implementation of potentially conflicting policies. ${ }^{73}$ The simultaneous membership of more than one REC can also force states to accept measures that may not necessarily be in their best interests. A pertinent example is that cited by Mapuva and Muyengwa-Mapuva, ${ }^{74}$ South Africa, Namibia, Botswana, Lesotho and Swaziland all belong to SACU. South Africa has already negotiated a Trade and Development Co-operation Agreement with the European Union (EU), as well as with the SACU. Hence, terms of any agreements concluded must also include the other SACU members.

Another concern created by overlapping membership is the potential for policy inconsistencies. Mapuva and Muyenga-Mapuva ${ }^{75}$ provide another example in the dual membership that Zambia holds of the SADC and COMESA. Under the SADC's free trade agreement, Zambia is required to exclude any trade barriers in the form of tariffs when dealing with any other member state. That is offset by the agreement made with COMESA, which requires the imposition of a common external tariff regime for any non-COMESA member. In the case of South Africa, which is a member of the SADC but not of COMESA, Zambia is forced to reject one of the agreements it has made with either of the two RECs if it aims to increase its trade with South Africa. If the SADC-EAC-COMESA Tripartite Free Trade Area (TFTA) is successfully established, it would help to overcome the challenges posed by overlapping memberships, as it aims to create a free trade agreement between all the SADC, COMESA and EAST African Community (EAC) member states. ${ }^{76}$

It is possible not to pass a final judgment of whether the SADC will succeed especially in view of the restructuring that have been put in place since it is still at the implementation stage. What can be said now is that the restructuring is addressing the key issues and that its main components - the centralization in Goborone and the phasing out of sector units and commissions - appear to have the support of member countries and stakeholders. All officials in member countries and sector coordinating units and commissions interviewed by the team supported the restructuring and were eager to see it work. There may be uncertainties about the specifics of the changes and the shift to Goborone but also a great loyalty to the decisions made. Solutions will however have to be found to a number of crucial issues. One revolves around the issue of SADC's operational capacity. ${ }^{77}$

\subsection{Comparing SADC and EU and other Regional Organizations in Africa}

By way of a comparative analysis, this researcher will look at SADC in the light of the European Union (EU) as a regional integration because the EU has been seen as a model template for regional integration. In 1950, six European countries - Belgium, France, Germany, Italy, Luxembourg and the Netherlands - established the European Coal and Steel Community (ECSC). This cooperation was soon enlarged to cover fields of atomic energy and general economic cooperation and two new organizations - EURATOM and European Economic Community (EEC) in 1958. The three organizations formed the European Communities in 1958 that relatively advanced the integration initiatives. The EC had a supranational organization with a Commission to administer the affairs of the organization and the court of justice with supranational jurisdiction. The ECC was a success as it was able to establish a common market in the field of economic policies, the European Court of Justice (ECJ) made several rulings that deepens the integration process, elections were held into the European Parliament.

The new beginning of the EC was experienced in the mid-1980s when the commission proposed the establishment of overdue common markets. This resulted in the signing of the Single European Act (SEA) which was paved way for by the European Monetary System (EMS). The European integration became deepened by the signing of the Maastricht Treaty that established the European Monetary Union and introduction of common currency - the Euro, at the beginning of 2002. In 2005, the cooperation became the European Union with 25 member states.

The competence of the union shows that it has a legal personality ${ }^{78}$ and under the principle of proportionality, the content and form of Union action shall not exceed what is necessary to achieve the objectives of the constitution..$^{79}$ This can be seen in the decision making. The EU for example sees that regional integration can act as a stepping stone on the way to reach the objective set out in the Maastricht Treaty, and therefore it tries to pursue Regional Economic Partnership Agreements with ACP-countries in the framework of the new Cotonou Agreement.

Comparing SADC and EU and Africa at large, regional cooperation organizations have not gained much political power and the integration processes have traditionally not included many political aspects, and therefore economic integration was the dominant form of integration in the African setting during the first wave of regional integration. It should be noted that economic integration is not detached from political integration. Theories of economic integration were based on the assumption that integration most likely follows a linear route, where cooperation is launched with the establishment of a preferential trade area, where participating countries apply lower tariffs to intra-regional trade. The next phase is usually the creation of a free trade area, which means that participating countries remove all tariff-barriers from their internal trade, but retain their own tariffs against the rest of the world. In a customs union, a common external tariff is adopted in addition to the free movement of products within the area. In a common market also labour and capital

\footnotetext{
${ }^{73}$ W Bell, 'The Southern African Development Community: Solid Achievements and Future Challenges' Strategic Analysis Paper, Independent Strategic Analysis of Australia's Global Interests, Published by Future Direction International pty Ltd, Australia 14 November 2017.

${ }^{74} \mathrm{~J}$ Mapuva and L Muyenga-Mapuva, "The SADC Regional Bloc: What Challenges and Prospects for Regional Integration? Law, Democracy and Development, University of the Western Cape, 18 (2014) para.4

$75 \mathrm{~J}$ Mapuva and L Muyenga-Mapuva (n53)

76 The involved states were not able to reach the deadline of June 2016 to settle any outstanding nego tiations on trade remedies and tariff offers and as a result, phase II negotiations were unable to commence. Subsequent attempts have seen progress, albeit slow, and more states, most notably South Africa, have now signed on the TFTA. See W Bell (n52)

${ }^{77} \mathrm{~J}$ Isaksen and $\mathrm{E} N$ Tjonneland at 21

${ }^{78}$ See Article 1-6

${ }^{79}$ Article 1-9
} 
movements have no restrictions. An economic union involves already a high degree of unification of monetary, fiscal and other policies. A political union is often seen as the ultimate stage of integration, and it involves also the integration of legislative and judicial processes. The SADC as well as other African integration processes ought to follow this route, but ran into difficulties already in the early phases of economic integration.

Firstly, the concept of permanent nature of membership: The ECSC stressed the need for membership not to be withdrawn on a unilateral decision. Previously membership withdrawal was to be regulated by Article 56(1) of the Vienna Convention on Law of Treaties, ${ }^{80}$ the new constitution includes a separate article about voluntary withdrawal from membership. ${ }^{81}$ Scholars have argued that with the adaptation of Article 1-59, withdrawal from the union will now be much easier. ${ }^{82}$ Naturally, it could be argued that the context has changed and the credibility of commitments does not have to be backed by unclear withdrawal procedures any longer. ${ }^{83}$ This position is radically different from that of SADC on issue of withdrawal as provided for in the Treaty. 84

Secondly, the role of the justice system in determining the integration process: The impact of the European Court of Justice (ECJ) in determining the scope and deepening the integration process cannot be overemphasized. Through the decisions of the ECJ the supremacy of the Union and its Treaty over Member States sovereignty has been established particularly in matters where the Treaty granted exclusive jurisdiction on the Union. ${ }^{85}$ The reverse is the case in SADC Tribunal as it is still not operational till date. Similarly, the ECOWAS Court of Justice though operational has been regarded as a toothless bull dog whose decisions are not obeyed.

Thirdly, the decision-making process in the EU is exclusive and involves different branches of the organization like the Commission, Council of Ministers, The European Council and the European Parliament. Although their participation in the decision making depends on their level of involvement and the issue at stake, however, there is a level playing field for all to partake. On the other hand, most of the decisions of the SADC are influenced by outside forces like the EU who is the major donor agent and the overshadowing influence of the dominant state member like South Africa.

\section{Conclusion}

The evolution of SADC as a formal, inter-state co-operation in Southern Africa is a relatively new phenomenon. However, the relevance of SADC in the African continent is undeniable. The discussion above has shown that SADC has tried to balance the conflicting interest in the region by trying to satisfy its own domestic, regional, continental and global demands on the economic integration front. The region is experiencing peace and deepening of democratic practices. Thus, at the moment when SADC is possibly moving into a new and more effective regional security actor as well as productive phase of its existence, there is the prospect of synergy with the NEPAD which will mean that SADC has much greater potential. However, the challenge to provide leadership at regional and global level has also been compounded by the domestic outcry for a need to deal with issues at home. Despite SADC's sophisticated security architecture, the behavior of its members suggest that they are not yet willing or able to share democratic political values and norms or harmonized national decision-making structures and practices in order to order to enhance SADC's ability or authority to make, implement and enforce its rules and decisions.

Van Nieuwkerk concludes that in order to meet the challenges of a globalizing, insecure and unequal world, SADC needs to pay much more attention to the operationalization of its organ protocol requirement of develop common foreign policy approaches to the issues of mutual concern' and advance such policy collectively in international fora. 86 The research finds out that multiple membership or members of the SADC are impeding the effective and efficient implementation of the programs and policies of the region. Recent indications are that South Africa appears to play a leading and dominance role in SADC particularly in area of economy which to some extent is posing a threat to other members of the region.

\section{Recommendation}

- There is need Continually strengthen the SADC's institutions, organs, and Centres of services and National Committees to become robust organizations to deliver tangible results; I agree with Isaksen and Tjonneland that, 'it is important for the Secretariat to be strengthened in capacity to monitor and evaluate the implementation of protocols and policies. This is also emphasized in the restructuring documents but so far it has received limited attention in the ongoing institutional restructuring.' ${ }^{27}$

- Harmonizing key SADC programmes with national strategic programmes and budgeting systems so that member states become catalysts in the implementation of SADC programs and protocols; such as a deeper integration that includes service, investment, competition policy and other behind-the- border issues capable of addressing national level supply side constraints far more effectively than an agenda that focuses almost exclusively on border measures. 88

\footnotetext{
${ }^{80}$ Joutsamo et al. 2000

${ }^{81}$ Article 1-59

${ }^{82}$ Heinonen (n4) at 108

${ }^{83}$ ibid

84 Pages $155-156$ of the SADC Treaty

${ }^{85}$ See the cases of Costa v ENEL, ECJ Judgment of 15 July 1964 Case 6/64 where Article 1-11 of the EU Treaty was interpreted. Also ECJ Judgment in a

Dutch case which judgment was delivered on the 5 February 1963, Case 26/62

${ }^{86}$ A van Nieuwkerk, SADC Common Foreign Policy, in Harvey, Proceedings, Pp 97-112 cited by A van Nieuwkerk (n13)

${ }^{87} \mathrm{~J}$ Isaksen and E N Tjonneland

${ }^{88}$ T Hartzenberg, 'Regional Integration in Africa' WTO Staff Working Paper. Economic Research and Statistics Division. Geneva: WTO 2011
} 
- Placing capacity development at the core of SADC's long-term mission for continual improvement on institutions at both Secretariat and member state levels. Effective mechanisms for strategy development, planning and especially for monitoring and evaluation of protocols and other core policies, are urgently required in SADC. 89 Such mechanisms need to be underpinned by a rules-based institutional framework that enhances compliance by member states. The current institutional mechanisms remain inadequate to foster greater policy and regulatory convergence among member states. ${ }^{90}$

- Repositioning of SADC to increase visibility and awareness as well as responding to internal and external factors affecting the implementation of integration agenda in the region. The World Bank argues ${ }^{91}$ that the appropriate metric for successful integration is reduction in the level of transaction costs that limit the capacity of Africans to move, invest and trade goods and services across, which calls for a different approach to one that proceeds within the straightjacket of specific sequential steps to integration. It is therefore vita for the SADC agenda to pay attention to microeconomic policies that used to be considered the exclusive domain of national economic policy. This approach seeks greater policy and regulatory 'harmonization' and adoption of best practices that will not only reduce diversity in the region but also improve the general business environment across borders by reducing costs and leveling the playing field for economic operators..$^{92}$

- SADC should make provision of compensating member states that are affected or loses that may accrue by the establishment of the Free Trade Area. This recommendation is based on the current happenings in the EU about Braxit.

- The problem of external funding is related to the pooling of sovereignty and negative influence on how the policies of the organization are being run. This researcher will recommend a budgetary support by member states to fund the programmes and policies of the organization.

\section{References}

i. L K Niekerk "Regional Integration: Concepts, Advantages, Disadvantages and Lesson of Experience" Available at www.siteresources.worldbank.org accessed 17 August 18, 2019

ii. S Kayizzi-Mugerwa, J C Anyanwu and P Conceicao, "Regional Integration in Africa: An Introduction" (2014) African Development Review, 26(1) Pp. 1-6

iii. H Heinonen "Regional Integration and the State: The Changing Nature of Sovereignty in Southern Africa and Europe" A Doctorate Dissertation Submitted to Institute of Development Studies (IDS) University of Helsinki 2006

iv. J Sidaway and R Gibb, "SADC, COMESA, SACU: Contradictory Formats for Regional 'Integration' in Southern Africa? In: Simon (ed) South Africa in Southern Africa: Reconfiguring the Region (James Curry, Oxford, 1998) $164-184$ at 170

v. E B Haas, "The Legacy of Neo-functionalism" Journal of European Public Policy (1968) 12(2) at 16. See also, P C Schmitter, "The Disparity of European Integration: Revisiting Neofunctionalism in Honour of Ernest Haas" Journal of European Public Policy (2005) 12 (2)

vi. I Wallerstein and S Vieira, 'Historical Development of the Region in the Context of the Evolving World-System' In: S Vieira, W Martin and I Wallerstein (eds), How Fast the Wind? Southern Africa, 1975-2000 (Trenton: Africa World Press, 1992)

vii. A van Nieuwkerk, Towards Peace and Security in Southern Africa: A Critical Analysis of the Revised Strategic Indicative Plan for the Organ on Politics, Defence and Security Co-operation of the Southern African Development Community' (Maputo-Mozambique, Friedrich Ebert Stiftung Publishers, 2012) at 8

viii. A Barlow, "The Southern African Development Community: History to 2001" (2015). Available at https://www.hsf.org.za accessed 18 August 2019.

ix. The IGD Guide to the Southern African Development Community (Johannesburg: Institute for Global Dialogue, 2001).

x. A van Nieuwkerk, Southern African Security Governance: A Cautionary Tale In: G Cawthra (ed), African Security Governance: Emerging Issues (Johannesburg: Wits University Press, 2009) at 108.

xi. J Isaksen and E N Tjonneland, "Assessing the Restructuring of SADC - Positions, Policies and Progress" A Report Commissioned by the Norwagian Agency for Development Co-operation (NORAD) December 2001

xii. J Maringwa, "SADC Regional Integration: What Role has Bilateral Trade Agreements Played in Promoting IntraRegional Trade? (2009) Trade and Industrial Policy Strategy (TIPS).

xiii. T Hartzenberg and P Kalenga, "National Policies and Regional Integration in the South African Development Community" United Nations University World Institute for Development Economics Research, Wider Working Paper 2015/056 (2015).

xiv. African Union "Regional Economic Communities (RECs): Southern African Development Community (SADC): Facts and (2011). Figures" Available at https://www.google.co.zw/?gws_rd=cr\&ei=3Qm3Ur6SG8jAtAbswoAY\#q=Regional+Economic+Communities+( RECs):+Southern +African+ Development+Community+(SADC)\%E2\%80\%9D+ Accessed 18 August, 2019

89 See SADC Policy for Strategy Development, Planning, Monitoring and Evaluation, approved by the Council of Ministers in February 2012 athttp://www.sadc.int/files/8713/6621/3373/SPME. Accessed 20 August 2019

$90 \mathrm{~T}$ Hartzenberg and $\mathrm{P}$ Kalenga

${ }^{91}$ World Bank, De-fragmenting Africa: Deeping Regional Trade Integration in Goods and Services (Washington, DC, World Bank Publications, 2012)

$92 \mathrm{~T}$ Hartzenberg and P Kalenga 
xv. M Berger and H Weber, "War, Peace and Progress: Conflict Development, (in)security and Violence in the 21st Century" Third World Quarterly, 30(1) 2009, Pp 1-16 and A van Nieuwkerk (n13).

xvi. J Mapuva and L Muyenga-Mapuva, "The SADC Regional Bloc: What Challenges and Prospects for Regional Integration? Law, Democracy and Development, University of the Western Cape, 18 (2014) para.4

xvii. SAPES, UNDP \& SADC: SADC Regional Human Development Report 2000: Challenges and Opportunities for Development (Harare: SAPES Books, 2000) and C Clapham et al. (ed.) "Regional Integration in Southern Africa: Comparative International Perspectives (Johannesburg: South Africa Institute of International Affairs, 2001)

xviii. J Isaksen and E N Tjonneland, "Assessing the Restructuring of SADC - Positions, Policies and Progress" A Report Commissioned by the Norwagian Agency for Development Co-operation (NORAD) December 2001. See also the Report of the Secretary- General, New York: UN General Assembly July 2001 (A/56/134) and T A Earsda\& J Claussen: Overview of the SADC Program and Donor Cooperation (Oslo: Nordic Consulting Group September 2001) Report Commission by NORAD)

xix. H Bienen, The Politics of Trade Liberalization in Africa" Economic Development and Cultural Change, (1990) 38(4), 713-732

xx. SADC Achievement Handbook, F G Mogae "SADC Major Achievements and Challenges: 25 Years of Regional Cooperation and Integration" 2005/.

xxi. Nathan L. "Solidarity triumphs over democracy - the dissolution of the SADC Tribunal" United Nations and regional challenges: Development dialogues, papers and comments (December 2011) at 124.

xxii. W Bell, "The Southern African Development Community: Solid Achievements and Future Challenges" Strategic Analysis Paper, Independent Strategic Analysis of Australia's Global Interests, Published by Future Direction International pty Ltd, Australia 14 November 2017.

xxiii. T Hartzenberg, "Regional Integration in Africa" WTO Staff Working Paper. Economic Research and Statistics Division. Geneva: WTO 2011

xxiv. SADC Policy for Strategy Development, Planning, Monitoring and Evaluation, approved by the Council of Ministers in February 2012 at http://www.sadc.int/files/8713/6621/3373/SPME. Accessed 20 August 2019

xxv. World Bank, De-fragmenting Africa: Deeping Regional Trade Integration in Goods and Services (Washington, DC, World Bank Publications, 2012)

xxvi. A van Nieuwkerk, SADC Common Foreign Policy, in Harvey, Proceedings, Pp 97-112 cited by A van Nieuwkerk (n13)

xxvii. SADC: Major achievements and challenges - 25th Anniversary 1980 - 2005 (2006) at 74. Available online at http://www.sadc.int/cms/uploads/SADC\%20Major\%20Achievements\%20Handbook\%20\%20English\%281\%29.pdf (accessed 17 July 2012).

xxviii. Costa v ENEL, ECJ Judgment of 15 July 1964 Case 6/64 where Article 1-11 of the EU Treaty was interpreted. Also ECJ Judgment in a Dutch case which judgment was delivered on the 5 February 1963, Case 26/62.

xxix. www.dfa.gov.za/foreign/multilateral/africa/sadc.htm. Accessed 8 August, 2019

xxx. www.jiclt.com/index.php/jiclt/article/view/74/73 Accessed 8 August, 2019

xxxi. www.internationaldemocracywatch.org 